\title{
Effect of Some Environmental Factors on Productive and Reproductive Performance of Egyptian Buffaloes
}

\author{
El -wakeel, EL.A ${ }^{1}$; Eissa, M.M ${ }^{1}$; Abdelsalam M.M ${ }^{2}$; Ahmed, M.H ${ }^{3}$; and El -Rewany, A.M ${ }^{1}$
}

\begin{abstract}
The study was carried out by the Department of Animal Production, Faculty of Agriculture, Alexandria University, Saba Bache, Alexandria, Egypt. Buffaloes were reared at Trust Farm. The farm is located in $\mathrm{Km} 40$ Alexandria-Cairo desert road after Ameria City. A trial was conducted to raise buffaloes in open sheds under routine managerial practice . The mean body weights of heifers at birth, weaning and first service, together with the high pre-weaning daily gain showed that the desert conditions did not exert adverse effects on it. The mean calving interval $(403.6 \pm 2.6$ days $)$ was near to the ideal calving interval which permits nearly a calf every year. Total milk yield per lactation averaged $1600 \pm 11 \mathrm{~kg}$. Such results indicated that the Egyptian buffaloes responded well to good managerial procedures. Year of calving affected significantly $(P<0.001)$ first service weight, daily gain from weaning to first service and from birth to first service, days open and lactation period. Season of calving and parity effects were significant $(P<0.001,0.01$ or 0.05$)$ on most of the traits studied. Also, Dry period affected days open $(p<0.001)$, lactation length $(p<0.001)$ and total milk yield $(p<0.001)$, however dry period didn't significantly affect calving interval. Days open was the highest in dry period (121-150 and $>150$ days) and the lowest in dry period (< 60, 60-90 and $91-120$ days). Lactation length was the highest in dry period (60 -90 days) and the lowest in dry period (121-150 and >150 days). Total milk yield was the highest in dry period (60-90 days) and the lowest in dry period (>150days).
\end{abstract}

Keywords: buffaloes, milk yield, reproductive performance

Abbreviation: THI = Temperature Humidity Index

\section{INTRODUCTION}

The buffalo is a milk producing species as well as an economically important source of meat in Egypt, buffaloes produce about $60 \%$ of the milk versus $40 \%$ for cattle, because buffaloes are the first choice of most Egyptian farmers. The buffalo milk is highly preferred by the public as well as by creameries due to its white color, sweet taste and high fat percentage. Buffalo milk production already corresponds to $12.1 \%$ of the world production, with an increase of $70.6 \%$ in the last 10

\footnotetext{
${ }^{1}$ Agriculture research center, Animal Research Institute, El-Dokki, Egypt.

${ }^{2}$ Animal Production Department, Faculty of Agriculture (El-Shatby)

Alexandria University.

${ }^{3}$ Faculty of Agriculture (Saba Basha) - Animal Production Department, Alexandria University.

Received December 20, 2012, Accepted March28, 2013
}

years (Santos et al., 2011). Productivities of buffalo are affected mainly by performance of reproductive female status. Reproduction efficiency is one of the most important factors for productivity and profitably of dairy animals and it's the primary factor affecting productivity in female buffalo, but is greatly hampered by late attainment of puberty, seasonality of calving, long postpartum anoestrus and subsequent calving interval.

Late or delayed estrus in buffalo heifers is one of the major factors limiting its overall productive and reproductive performance. Feeding and general management have been reported to improve reproduction efficiency of buffaloes (Jabalkandi et al., 2010).

According to Bagnato and Oltenacu (1993), milk yield and fertility are the main factors that affect the profitability of milk herds. As the milk yield is related to the variations in the reproductive activity, then the shorter calving intervals can be associated to bigger milk production during the animal's productive life, besides the possible increase in the number of calves per year.

The buffalo should be dried off approximately 2 to 3 months before expected calving. The dry period is valuable to the buffalo, she may rest and the udder tissue is repaired. In a high yielding herd (above $10 \mathrm{~kg}$ per day) the buffalo should be dried off when the daily yield falls below $2.5 \mathrm{~kg}$, even if it is still more than 3 months to expected calving. This goes especially for machine milked herds. The aim of the present investigation was to study the growth, some productive and reproductive traits of buffaloes as affected by some environmental factors

\section{MATERIALS AND METHODS}

The study was conducted on buffaloes herd that reared at trust Farm. The farm is located in $\mathrm{Km} 40$ Alexandria-Cairo desert road after Ameria city.

\section{Materials}

The buffaloes were housed in open sheds similar to those used for cattle. Maximum and minimum ambient air temperatures in the sheds during the period of the 
study (three years) were $21.9 \pm 1.1$ and $9.8 \pm 0.4$ in winter, $33.1 \pm 1.4$ and $22.8 \pm 0.4$ in spring, $34.2 \pm 5.9$ and $23.8 \pm 0.8$ in summer and 28.2 \pm 4.1 and 17.4 $\pm 3.0 \mathrm{C}^{0}$ in autumn and relative humidity percentages were $65.1 \pm 1.4,56.4 \pm 2.4$, $66.3 \pm 0.8$ and $58.8 \pm 5.0$, in the same seasons, respectively.

Animals were kept under a regular system of feeding recommended by Animal Production Institute, Ministry of Agriculture, Egypt. Feeds were offered according to the requirements of body weight, reproductive status and milk production. A concentrate mixture, green fodder [Egyptian clover (Trifolium alexandrinum) during winter and spring or Pioneer maize plants and corn silage during summer and autumn], in addition to Egyptian clover hay, rice or wheat straw, were provided.

Female were weaned at 4.5 months of age . Heifers being added to the breeding stock received first service when they reached a body weight of $330 \mathrm{~kg}$. Calving in Egypt is preferred to be during September and October months, due to the availability of green fodder (Egyptian clover) in abundance and the mild weather that prevails during the following months. Pluriparous cows were mated two months after calving. Matings were performed naturally at random under group breeding (one bull with 50 buffalo cows). The animals were grouped according to parity number (1-5 ), Dry period $(1=<60 ; 2=60-90 ; 3=91-120 ; 4=121-150$ and $5=>$ 150 days). Lactating animals were hand milked twice daily at 7.00 and $19.00 \mathrm{~h}$.

All animals were healthy and clinically free of external and internal parasites and were kept, maintained and treated in adherence to accepted standards for the humane treatment of animals.

\section{Methods}

Data of body weight and growth were obtained on female calves born during two years and these of lactation records were collected on dams born during three years. Both procedures were begun at the same time. Body weights were studied on 71 buffalo female calves, from birth to first service.

Milk yield and related traits were studied on milking animals in the farm, during five consecutive parities. The number of lactations used in the study was 220 pertaining to 115 buffalo cows. Only records of lactations that continued for at least 150 days were considered normal and were used in the analysis of milk production traits, while those lasting for a period less than 150 days and/or those of cows were affected by mastitis or other udder disorders, as well as those of doubtful information, were excluded.

\section{Statistical analysis:}

Data were statistically analyzed using GLM procedure according to SAS (1999). The model concern body weight and gain was as follows:

$\mathrm{Y}_{\mathrm{ijkl}}=\mu+\mathrm{G}_{\mathrm{i}}+\mathrm{W}_{\mathrm{j}}+\mathrm{M}_{\mathrm{k}}+\mathrm{e}_{\mathrm{ijkl}}$

Where:

$\mathrm{Y}_{\mathrm{ijkl}}=$ An observation on individual 1

$\mu=$ overall mean

$\mathrm{G}_{\mathrm{i}}=$ Fixed effect of the $\mathrm{i}^{\text {th }}$ year of birth.

$\mathrm{W}_{\mathrm{j}}=$ Fixed effect of the $\mathrm{j}^{\text {th }}$ season of birth .

$\mathrm{M}_{\mathrm{k}}=$ Fixed effect of the $\mathrm{k}^{\text {th }}$ parity.

$\mathrm{e}_{\mathrm{ijkl}}=$ random error normally distributed with mean $=$ zero and variance $=\sigma^{2} \mathrm{e}$

The second models which describe milk traits and reproductive traits was as follows:

$\mathrm{Y}_{\mathrm{ijklm}}=\mu+\mathrm{G}_{\mathrm{i}}+\mathrm{W}_{\mathrm{j}}+\mathrm{M}_{\mathrm{k}}+\mathrm{S}_{\mathrm{l}}+\mathrm{e}_{\mathrm{ijklm}}$

Where:

$\mathrm{Y}_{\mathrm{ijklm}}=$ An observation on individual $\mathrm{m}$

$\mu=$ overall mean

$G_{i}=$ Fixed effect of the $i^{\text {th }}$ year of calving.

$\mathrm{W}_{\mathrm{j}}=$ Fixed effect of the $\mathrm{j}^{\text {th }}$ season of calving.

$\mathrm{M}_{\mathrm{k}}=$ Fixed effect of the $\mathrm{k}^{\text {th }}$ parity.

$\mathrm{S}_{\mathrm{l}}=$ Fixed effect of the $1^{\text {th }}$ dry period.

$\mathrm{e}_{\mathrm{ijklm}}=$ random error normally distributed with mean $=$ zero and variance $=\sigma^{2} \mathrm{e}$

Significance differences among means were detected using Duncan's Multiple Range Test.

\section{RESULTS AND DISCUSSIONS}

\section{Performance of cow traits}

Means of body weights of buffalo heifers were $43.0 \pm 0.5,135.8 \pm 0.4$ and $372.2 \pm 2.0 \mathrm{~kg}$ at birth, weaning and first service, respectively (Table1). The averages of body weights at birth, weaning and first service were higher than that recorded in the Nile Valley (Tantawy,1984) or under similar newly reclaimed desert conditions (Mohamed, 2000). The higher average weights, together with the higher pre-weaning daily gain than that reported by Mohamed (2000) and Marai et al., (2009) indicated that the desert conditions did not exert adverse effects on the growth of calves. Averages of daily weight gain were $0.670 \pm 0.01,0.590 \pm 0.01$ and $0.613 \pm 0.01 \mathrm{~kg}$ between birth and weaning, weaning and first service and from birth to first service, respectively (Tables 1 and 3). 
Effects of some environmental factors on body weight and gain

Temperature-humidity index (THI) calculated for maximum temperature during winter was 21.1, ranged between 21.6 and 30.6 during spring, 22.8 and 32.1 during summer and 17.0 and 26.4 during autumn, indicating absence of heat stress during winter and exposure to very severe heat stress during the other seasons, with the highest Temperature Humidity Index value during summer. year effects were significant on weight at first service $(\mathrm{P}<0.001)$, daily gain from weaning to $1^{\text {st }}$ service $(\mathrm{P}<0.001)$ and daily gain from birth to $1^{\text {st }}$ service $(\mathrm{P}<0.001)$ (Tables 2,3$)$
Season of birth affected birth weight $(\mathrm{P}<0.001)$, weight at first service $(\mathrm{P}<0.05)$ and average daily gain from birth to weaning $(\mathrm{P}<0.05)$ and from weaning to first service $(\mathrm{P}<0.001)$ (Tables 2 and 3$)$. Birth weight was the heaviest in winter, spring and autumn and the lightest in summer. Weight at first service was the heaviest in winter and the lightest in spring (Table 2).

Daily weight gain between birth and weaning was the highest in spring and the lowest in summer, and daily gain weight between weaning and first service was the highest in summer and autumn and the lowest in spring and winter births (Table 3).

Table 1. Means ( \pm S.E) and coefficients of variation $(\mathrm{CV} \%)$ of buffalo cow traits under study

\begin{tabular}{lccc}
\hline Traits & No. & Mean \pm SE & C.V\% \\
\hline Birth weight, kg & 71 & $43.0 \pm 0.5$ & 14.1 \\
Weaning weight, kg & 71 & $135.8 \pm 0.4$ & 3.3 \\
Weight at first service, kg & 71 & $372.2 \pm 2.0$ & 8.0 \\
Average daily gain, kg & & & \\
Birth - weaning & 71 & $0.670 \pm 0.01$ & 17.9 \\
Weaning - first service & 71 & $0.590 \pm 0.01$ & 16.8 \\
Birth - first service & 71 & $0.613 \pm 0.01$ & 11.9 \\
Age at first calving, months & 71 & $25.2 \pm 0.6$ & 36.8 \\
Days open, days & 218 & $92.8 \pm 1.3$ & 51.1 \\
Lactation length, days & 195 & $245.1 \pm 1.2$ & 17.6 \\
Calving interval, days & 181 & $403.6 \pm 2.6$ & 14.6 \\
Total milk yield, kg & 181 & $1600.0 \pm 11.0$ & 25.5 \\
\hline
\end{tabular}

Table 2. Least squares means $( \pm$ S.E) of factors affecting birth, weaning and first service weights of Egyptian buffalo heifers

\begin{tabular}{|c|c|c|c|c|}
\hline Factors & No. & $\begin{array}{c}\text { Birth weight, } \\
\text { kg }\end{array}$ & $\begin{array}{c}\text { Weaning weight, } \\
\text { Kg }\end{array}$ & $\begin{array}{c}\text { Weight at first service, } \\
\text { Kg }\end{array}$ \\
\hline Overall means & 71 & $43.0 \pm 0.5$ & $135.8 \pm 0.4$ & $372.2 \pm 2.0$ \\
\hline \multicolumn{5}{|l|}{ Year of birth } \\
\hline $1^{\text {st }}$ year & 31 & $43.9 \pm 1.2$ & $136.0 \pm 1.1$ & $349.0^{\mathrm{b}} \pm 4.8$ \\
\hline $2^{\text {nd }}$ year & 40 & $43.7 \pm 0.7$ & $135.4 \pm 0.6$ & $373.3^{\mathrm{a}} \pm 2.7$ \\
\hline Significance & & $\mathrm{NS}$ & $\mathrm{NS}$ & $* * *$ \\
\hline \multicolumn{5}{|l|}{ Season of birth } \\
\hline Winter & 17 & $46.6^{\mathrm{a}} \pm 1.2$ & $137.2 \pm 1.1$ & $369.8^{a} \pm 4.8$ \\
\hline Spring & 14 & $44.4^{\mathrm{a}} \pm 2.0$ & $134.3 \pm 1.9$ & $344.7^{b} \pm 8.2$ \\
\hline Summer & 14 & $40.0^{b} \pm 0.8$ & $134.1 \pm 0.8$ & $364.5^{\mathrm{a}} \pm 3.3$ \\
\hline Autumn & 26 & $44.0^{\mathrm{a}} \pm 0.9$ & $135.9 \pm 0.8$ & $368.4^{a} \pm 3.6$ \\
\hline Significance & & $* * *$ & NS & $*$ \\
\hline \multicolumn{5}{|l|}{ Parity } \\
\hline $1^{\mathrm{st}}$ & 11 & $42.0 \pm 1.2$ & $136.8 \pm 1.1$ & $368.1 \pm 4.8$ \\
\hline $2^{\text {nd }}$ & 14 & $44.1 \pm 1.3$ & $136.2 \pm 1.3$ & $364.4 \pm 5.5$ \\
\hline $3^{\text {rd }}$ & 16 & $46.3 \pm 1.5$ & $134.7 \pm 1.4$ & $360.3 \pm 6.2$ \\
\hline $4^{\text {th }}$ & 14 & $45.6 \pm 1.4$ & $134.5 \pm 1.3$ & $366.6 \pm 5.7$ \\
\hline $5^{\text {th }}$ & 16 & $43.9 \pm 1.7$ & $136.3 \pm 1.6$ & $361.2 \pm 6.9$ \\
\hline Significance & & NS & $\mathrm{NS}$ & NS \\
\hline
\end{tabular}

Means bearing different superscripts within the same class differ significantly at $\mathrm{P}<0.05$,

$* \mathrm{P}<0.05, * * * \mathrm{P}<0.001, \mathrm{NS}=$ Not significant. No.$=$ number of observation 
Table 3. Least squares means $( \pm$ S.E.) of factors affecting daily gain weight of Egyptian buffalo heifers

\begin{tabular}{|c|c|c|c|c|}
\hline Factors affecting & No of observations & $\begin{array}{c}\text { Birth - weaning, } \\
\text { kg } \\
\end{array}$ & $\begin{array}{c}\text { Weaning }-1^{\text {st }} \text { service, } \\
\mathrm{kg}\end{array}$ & $\begin{array}{c}\text { Birth }-1^{\text {st }} \text { service, } \\
\mathbf{K g} \\
\end{array}$ \\
\hline Overall means & 71 & $0.670 \pm 0.01$ & $0.590 \pm 0.01$ & $0.613 \pm 0.01$ \\
\hline \multicolumn{5}{|l|}{ Year of birth } \\
\hline $1^{\text {st }}$ year & 31 & $0.709 \pm 0.02$ & $0.432^{\mathrm{b}} \pm 0.02$ & $0.527^{\mathrm{b}} \pm 0.01$ \\
\hline $2^{\text {nd }}$ year & 40 & $0.677 \pm 0.01$ & $0.606^{\mathrm{a}} \pm 0.01$ & $0.626^{\mathrm{a}} \pm 0.01$ \\
\hline Significance & & NS & $* * *$ & $* * *$ \\
\hline \multicolumn{5}{|l|}{ Season of birth } \\
\hline Winter & 17 & $0.674^{\mathrm{b}} \pm 0.02$ & $0.482^{\mathrm{b}} \pm 0.02$ & $0.567 \pm 0.01$ \\
\hline Spring & 14 & $0.775^{\mathrm{a}} \pm 0.04$ & $0.487^{\mathrm{b}} \pm 0.03$ & $0.588 \pm 0.02$ \\
\hline Summer & 14 & $0.647^{\mathrm{c}} \pm 0.02$ & $0.579^{\mathrm{a}} \pm 0.01$ & $0.594 \pm 0.01$ \\
\hline Autumn & 26 & $0.676^{\mathrm{b}} \pm 0.02$ & $0.563^{\mathrm{a}} \pm 0.01$ & $0.595 \pm 0.01$ \\
\hline Significance & & $*$ & $* * *$ & NS \\
\hline \multicolumn{5}{|l|}{ Parity } \\
\hline $1^{\text {st }}$ & 11 & $0.706^{\mathrm{b}} \pm 0.02$ & $0.525 \pm 0.02$ & $0.582^{\mathrm{a}} \pm 0.01$ \\
\hline $2^{\text {nd }}$ & 14 & $0.724^{\mathrm{a}} \pm 0 . .03$ & $0.523 \pm 0.02$ & $0.576^{\mathrm{a}} \pm 0.02$ \\
\hline $3^{\text {rd }}$ & 16 & $0.588^{\mathrm{c}} \pm 0.03$ & $0517 \pm 0.02$ & $0.554^{\mathrm{b}} \pm 0.02$ \\
\hline $4^{\text {th }}$ & 14 & $0.694^{\mathrm{b}} \pm 0.03$ & $0.531 \pm 0.02$ & $0.586^{\mathrm{a}} \pm 0.02$ \\
\hline $5^{\text {th }}$ & 16 & $0.691^{\mathrm{b}} \pm 0.03$ & $0.509 \pm 0.02$ & $0.565^{\mathrm{bc}} \pm 0.02$ \\
\hline Significance & & $*$ & NS & $* * *$ \\
\hline
\end{tabular}

Means bearing different superscripts within the same class differ significantly at $\mathrm{P}<0.05, * \mathrm{P}<0.05, * * * \mathrm{P}<0.001, \mathrm{NS}=\mathrm{Not}$ significant. No. = number of observation .

The effect of season of birth on birth weight in the present study was similar to the results of Eid (1988), Zaki (1988) and Marai et al (2009) who reported that the heaviest calf weights at birth were produced by either spring or winter calvers. The lowest birth weightand average daily gain between birth and weaning of summer-born calves may be attributed to suffering of the foetus from the adverse effects resulting from exposure of their dams during late pregnancy to moderate to very severe heat stress (THI $=22.8$ to 32.8 during summer). Parity effects were significant on growth traits. These traits were daily weight gain from birth to weaning $(\mathrm{P}<0.05)$ and from birth to first service ( $\mathrm{P}<0.01)$. (Tables 2, 3)

\section{Reproductive and productive traits:}

Averages of days open, lactation length, and calving interval were $92.8 \pm 1.3,245.1 \pm 1.2$, and $403.6 \pm 2.6$ days, respectively (Table 1$)$. Length of days open $(92.8 \pm 1.3$ days) was much lower than that recorded by Roy Choudhury (1971) in Italian buffaloes (range 97-316 days), El-Wishy (1979) in Iraqi buffaloes, Govindaiah and Rai (1987) in Indian buffaloes, Eid (1988) and Marai et al (2009) in Egyptian buffaloes. Such phenomenon may be attributed to serving the cows at the suitable time, in addition to the adequate plane of nutrition offered in the present study. Days open, calving interval and lactation length were affected $(\mathrm{P}<0.001$ or 0.01 ) by season of calving (Tables 4 and 5) The lowest length of each of day's open and calving interval was during summer and autumn and that of lactation length was in summer calves (Table4). The significant effects of season of calving on days open, calving interval and lactation length were similar to that reported by Alim and Taher (1979) and Marai et al (2009). The lowest estimates shown in days open and calving interval during autumn and in lactation length during summer, were similar to that reported by ElKhaschab et al (1984) and Marai et al (2009).

Lactation length (245.1 \pm 1.2 days) was longer than the value recorded by Zaki (1988) (195 days) and Marai et al (2009) (244 days), but shorter than that reported by Zeidan (1990) (286 days) and by Mohamed (2000) (269.8 days), in Egyptian buffaloes. [This length fell within the range reported by Skalicki and Latinovic (1990) and Juneja et al (1991) who recorded almost similar results (344 days)]. However a shorter means (291.86 \pm 6.55 days) was stated by Sattar et al (2005) and 
Alim (1986) in Libya. In this study LL is not significantly affected by year of calving, season of calving and parity number. The non significant effect of year of calving is agreed with Dhumal et al (1989) and Marai et al (2009) and disagreed with Karan and Joshi (1990). Njubi et al (1992) supported the non significant effect of parity on the trait . The results revealed that cows calved in winter lactated for longer period than those calved in other seasons. Whereas Nartey (1990) reported that cows calved in the rainy season had longer lactation length than those calved in dry season. The average length of calving interval (403.6 \pm 2.6 days) was very near to the ideal calving interval that permits nearly a calf each year. This indicated that Egyptian buffaloes responded well to good managerial procedures.
Mohamed (2000) reported the calving interval of 464.3 days, under newly reclaimed desert.

Total milk yield per lactation averaged $1600 \pm 11 \mathrm{~kg}$. and being higher than that recorded by Mohamed (2000) under similar newly reclaimed desert conditions $(1171 \mathrm{~kg})$. The peak of milk production was reached in the fourth and fifth parities similar to that reported by El-Menshawy (1994) and Marai et al (2009). This amount was more than that reported by Morsy et al. (1990) while it is less than the findings of Gwaza et al (2007) in Cameroon, Ahmed et al (1997) in Libya and Petrovic (1992) in Yugoslavia. This shows that there are great variations in milk yield in different places. This could be attributed to variation in managerial practices such as nutrition, disease control in addition to the effect of climatic conditions.

Table 4. Least squares means ( \pm S.E.) of factors affecting days open and calving interval, of Egyptian buffalo cows

\begin{tabular}{|c|c|c|c|c|}
\hline Factors & No. & Days open, days & No. & Calving interval, days \\
\hline Overall means & 218 & $92.8 \pm 1.3$ & 181 & $403.6 \pm 2.6$ \\
\hline \multicolumn{5}{|l|}{ Year of calving } \\
\hline $1^{\text {st }}$ & 60 & $96.9^{\mathrm{a}} \pm 6.7$ & 37 & $382.4 \pm 15.0$ \\
\hline $2^{\text {nd }}$ & 70 & $101.0^{\mathrm{a}} \pm 4.1$ & 53 & $384.2 \pm 8.2$ \\
\hline $3^{\text {rd }}$ & 88 & $61.4^{\mathrm{b}} \pm 3.1$ & 91 & $386.4 \pm 4.6$ \\
\hline Significance & & $* * *$ & & $\mathrm{NS}$ \\
\hline \multicolumn{5}{|c|}{ Season of calving } \\
\hline Winter & 47 & $91.8^{\mathrm{b}} \pm 5.2$ & 38 & $395.7^{\mathrm{b}} \pm 10.1$ \\
\hline Spring & 41 & $98.9^{\mathrm{a}} \pm 6.5$ & 26 & $401.7^{\mathrm{a}} \pm 12.3$ \\
\hline Summer & 68 & $82.7^{\mathrm{c}} \pm 4.6$ & 58 & $383.7^{\mathrm{c}} \pm 9.5$ \\
\hline Autumn & 62 & $80.0^{c} \pm 4.6$ & 59 & $371.3^{\mathrm{d}} \pm 9.3$ \\
\hline Significance & & $* * *$ & & $* *$ \\
\hline \multicolumn{5}{|l|}{ Parity } \\
\hline $1^{\mathrm{st}}$ & 52 & $113.2^{\mathrm{a}} \pm 3.1$ & 33 & $480.1^{\mathrm{a}} \pm 23.6$ \\
\hline $2^{\text {nd }}$ & 42 & $101.6^{\mathrm{ab}} \pm 3.4$ & 35 & $429.3^{\mathrm{b}} \pm 17.2$ \\
\hline $3^{\text {rd }}$ & 44 & $90.0^{\mathrm{b}} \pm 3.6$ & 28 & $401.0^{c} \pm 11.2$ \\
\hline $4^{\text {th }}$ & 49 & $83.1^{\mathrm{b}} \pm 3.8$ & 43 & $378.2^{\mathrm{d}} \pm 6.7$ \\
\hline $5^{\text {th }}$ & 31 & $86.1^{\mathrm{b}} \pm 4.0$ & 42 & $365.4^{\mathrm{d}} \pm 7.0$ \\
\hline Significance & & $* * *$ & & $* *$ \\
\hline \multicolumn{5}{|c|}{ Dry period ( days ) } \\
\hline$<60$ & 32 & $85.6^{\mathrm{b}}+4.1$ & 31 & $366.4+3.9$ \\
\hline $60-90$ & 50 & $83.2^{\mathrm{b}}+2.9$ & 50 & $370.1+3.2$ \\
\hline $91-120$ & 43 & $88.2^{\mathrm{b}}+3.9$ & 42 & $377.4+3.7$ \\
\hline $121-150$ & 42 & $104.2^{\mathrm{ab}}+3.7$ & 28 & $387.6+4.6$ \\
\hline$>150$ & 51 & $112.3^{\mathrm{a}}+2.9$ & 30 & $390.3+4.1$ \\
\hline Significance & & $* * *$ & & NS \\
\hline
\end{tabular}

Means bearing different superscripts within the same class, differ significantly $(\mathrm{P}<0.05)$. ${ }^{* * *} \mathrm{P}<0.001,{ }^{*} * \mathrm{P}<0.01, \mathrm{NS}=\mathrm{Not}$ Significant and No. $=$ number of observations 
Table 5. Least squares means ( \pm S.E.) of factors affecting total milk yield and lactation length of Egyptian buffalo cows

\begin{tabular}{|c|c|c|c|}
\hline Factors & No. & Total milk yield, kg & Lactation length, Days \\
\hline Overall means & 181 & $1600.0 \pm 11.0$ & $245.1 \pm 1.2$ \\
\hline \multicolumn{4}{|l|}{ Year of calving } \\
\hline $1^{\text {st }}$ & 53 & $1562.3^{b} \pm 93.2$ & $272.2 \pm 10.5$ \\
\hline $2^{\text {nd }}$ & 57 & $1502.0^{\mathrm{c}} \pm 50.3$ & $269.4 \pm 5.5$ \\
\hline $3^{\text {rd }}$ & 71 & $1596.3^{\mathrm{a}} \pm 30.0$ & $259.0 \pm 3.1$ \\
\hline Significance & & $* * *$ & NS \\
\hline \multicolumn{4}{|c|}{ Season of calving } \\
\hline Winter & .42 & $1550.3^{\mathrm{b}} \pm 58.7$ & $263.7^{\mathrm{a}} \pm 6.6$ \\
\hline Spring & 31 & $1609.3^{\mathrm{a}} \pm 65.3$ & $262.7^{\mathrm{a}} \pm 7.3$ \\
\hline Summer & 62 & $1641.3^{\mathrm{a}} \pm 51.7$ & $239.7^{\mathrm{b}} \pm 5.7$ \\
\hline Autumn & 46 & $1501.7^{\mathrm{c}} \pm 56.7$ & $251.3^{\mathrm{ab}} \pm 6.3$ \\
\hline Significance & & $* *$ & $* * *$ \\
\hline \multicolumn{4}{|l|}{ Parity } \\
\hline $1^{\mathrm{st}}$ & 29 & $1486.4^{\mathrm{d}} \pm 167$ & $227.3^{\mathrm{b}} \pm 19.0$ \\
\hline $2^{\text {nd }}$ & 36 & $1610.2^{c} \pm 123$ & $242.3^{\mathrm{ab}} \pm 14.0$ \\
\hline $3^{\text {rd }}$ & 37 & $1597.0^{\mathrm{c}} \pm 87.4$ & $245.2^{\mathrm{a}} \pm 9.9$ \\
\hline $4^{\text {th }}$ & 39 & $1652.3^{\mathrm{b}} \pm 55.5$ & $246.4^{\mathrm{a}} \pm 6.2$ \\
\hline $5^{\text {th }}$ & 40 & $1685.0^{\mathrm{a}} \pm 39.5$ & $247.2^{\mathrm{a}} \pm 4.3$ \\
\hline Significance & & $* * *$ & $* * *$ \\
\hline
\end{tabular}

\begin{tabular}{lccc}
\hline Dry period (days) & & & \\
\hline$<60$ & 49 & $1603.7^{\mathrm{bc}}+65.3$ & $234.6^{\mathrm{bc}}+11.4$ \\
\hline $60-90$ & 36 & $1690.2^{\mathrm{a}}+122.6$ & $245.5^{\mathrm{a}}+8.9$ \\
\hline $91-120$ & 38 & $1655.6^{\mathrm{b}}+57.8$ & $239.7^{\mathrm{b}}+7.9$ \\
\hline $121-150$ & 30 & $1608.4^{\mathrm{bc}}+40.1$ & $232.5^{\mathrm{bc}}+9.3$ \\
\hline$>150$ & 28 & $1481.3^{\mathrm{c}}+159.3$ & $228.5^{\mathrm{c}}+18.4$ \\
\hline Significance & & $* * *$ & $* * *$ \\
\hline
\end{tabular}

Means bearing different superscripts within the same class, , differ significantly $(\mathrm{P}<0.05) . * * * \mathrm{P}<0.001 .{ }^{* *} \mathrm{p}<0.01$ and NS $=$ Not significant. No. $=$ number of observation

Parity effects were significant on reproductive and productive traits. These traits were days open $(\mathrm{P}<0.001)$, lactation length $(\mathrm{P}<0.001)$, calving interval $(\mathrm{P}<0.001$ and total milk yield $(\mathrm{P}<0.001)$ (Tables 4 and 5). In general, day's open, and calving interval decreased, while lactation length increased with advancement of parity (Tables 4 and 5). The significant effect of parity on days open was similar to the findings of Marai et al (2009) and different from those of Mohamed (1974). The tendency of the length of days open to decrease from the first parity onwards may be a result of culling buffaloes with lower fertility.

The decrease in calving interval with advancement of parity was similar to that reported by Mourad (1978) and Marai et al (2009). Such a trend may be a reflection of the same practice of culling buffalo cows that show lower fertility in their early parities. The highly significant effect $(\mathrm{P}<0.001)$ of parity on calving interval in buffaloes was similar to that reported by ElMenshawy (1994) and Marai et al (2009) in Egyptian buffaloes.

Dry period affected days open $(\mathrm{p}<0.001)$, lactation length $(p<0.001)$ and total milk yield $(p<0.001)$, however dry period didn't significantly affect calving interval (table 4 and 5). Days open was the highest in dry period (121-150 and $>150$ days) and the lowest in dry period $(<60,60-90$ and $91-120$ days). Lactation length was the highest in dry period (60-90 days) and 
the lowest in dry period (121-150 and > 150 days). Total milk yield was the highest in dry period (6090days) and the lowest in dry period (> 150 days). The significant effects of dry period on days open, total milk yield and lactation length were similar to that reported by Alim and Taher (1979) and Marai et al (2009). The lowest estimates shown in days open and lactation length during dry period $(<60,60-90$ and $91-120$ days $)$ and dry period (121-150 and $>150$ days) respectively were similar to that reported by El-Khaschab et al (1984).

\section{CONCLUSIONS}

Averages of female buffalo growth and reproductive performance traits obtained in the present study indicated that the desert conditions did not exert adverse effects on the traits, and buffaloes responded well to the good managerial procedures, without wallowing.

\section{REFERENCES}

Ahmed, M.K.A, Kharoofa, A.D S, Salhab, S A \& Zoied, A. A. (1997). Comparative performance of imported and homebred Holstein Friesian cows. Almukhtar for science, (3), 9-21

Alim,K.A and Taher, A. (1979). The performance of Friesian and buffalo calves. World Review of Animal Production 1: $71-80$

Alim,K.A.(1986). Aspects of animal production in Libya. World Rev. Anim. Prod., (21), 33-38.

Ayyat,M.S.,Marai,I. F. M and El-Shafei,O.M (1996). Factors affecting adjusted milk yield for lactation length in Egyptian buffaloes and their pattern of inheritance. Indian Journal of Animal Sciences 66: 607-613

Bagnato,A and Oltenacu,P.A (1993). Genetic study of fertility traits and production in different parities in Italian Frisian cattle. Journal of Animal Breeding Genetics 110:126-134.

Dhumal,M.V.,Sakhare, P.S and Deshpande K S. (1989). Milk yield .per day for lactation length and milk yield day of calving interval in Red Kandhari and crossbred cows. Indian J. Anim. Sci., 58 (10), 1217- 1220.

Eid,N.L.(1988). Environmental influence on the productive and reproductive performance of the Egyptian Water buffaloes. M.Sc. Thesis, University of Ain-Shams, Cairo, Egypt.

El-Khaschab,S., El-Danasoury,M.S and Omar.S (1984). Studies on some reproductive and productive traits of buffaloes in Egypt. Minufiya Journal of Agricultural Research 9: 211-

El-Masry,K.Aand Marai,I.F.M (1991). Comparison between Friesians and water buffaloes in growth rate, milk production and some blood constituents, during winter and summer conditions of Egypt. Animal Production 53: $39-43$.
El-Menshawy,S.M.S (1994). Studies on productive and reproductive efficiency of Egyptian buffaloes. Ph.D. Thesis, Zagazig University, Zagazig, Egypt.

El-Wishy,A.B (1979). Reproductive performance of Iraqi buffaloes. 1. Pattern of female reproduction. Beitrage Zur Tropischen Landuirtschaft und Veterinarmedizin 17: 77-83

Govindaiah, M. G and Rai, A .V (1987). Productive and reproductive traits of medium size buffaloes. Indian Journal of Dairy Science 40: 333-339

Gwaza,D.S, Okwori,A.I.,Abu,A.H and Fombah,E.M.(2007). A retrospective study on reproductive and dairy performance of Holstein Friesian on zero grazing in the western highland regions of Cameroon. Livestock Research for Rural Development, 19 (4) 2007 cited in http://www.lrrd.org/lrrd19/4/gwaz19057.htm

Jabalkandi,A;Gh.Manafiaza and S.Razzagzadeh (2010). Effect of supplemented ration on some reproductive traits in Azeri buffaloes of Iran Italian Journal of Animal Science 14:15:06

Khalil,M.H (1993). Days open adjustment factors and genetic evaluation for lactation traits in Egyptian buffaloes. Annals of Agriculture Science, Moushtohor 31 (2): 865-884

Junejal,J.N.,Sastry,S.R and Yadav,B.L.(1991). Performance of purebred herd of Jersey and Holstein-Friesian cows in the semi-arid region. Indian J.Anim.Prod.Management, 7, 240-241

Karan,P.K and Joshi,B.K.(1990). Factors affecting first lactation production and reproduction traits of karan swiss cattle. Indian J. Anim. Sci., 60 (2), 223-227.

Marai, I.F.M., Daader, A.H., Soliman, A.M. and ElMenshawy, S.M.S. (2009). Non-genetic factors affecting growth and reproduction traits of buffaloes under dry management housing (in sub-tropical environment) in Egypt. Livestock Research for Rural Development.21:3

Misra,R.C., Kushwaha, N. S and Singh, R (1986). Study on age at first calving in Murrah and Bhadawari buffaloes. Indian Veterinary Medicine Journal 10(1): 13--15

Mohamed,A.A(1974). Physiological changes in the reproductive organs of buffaloes from parturition to conception. Ph.D. Thesis, University of Ain-Shams, Cairo, Egypt.

Mohamed, I. A. S (2000). The performance of Egyptian buffaloes under newly reclaimed desert lands.. M.Sc. Thesis, Faculty of Agriculture, Zagazig University, Zagazig, Egypt.

Moharram, A.A (1988). Reproduction and dairy performance of Holstein Friesian cattle in Egypt. Revue d'elevage et de Mèdicine Vètérinaire des Pays Tropicauxiliary 11: 209-213

Mohamed Khair,A.A.,Ahmed, B T Lutfi M A \& Kurt J B. (2007). Milk production and reproduction traits of different grades of zebu x Friesian crossbred,s under semiarid conditions. Cited in http://arch-animbreed.fbndummerstorf.de/pdf/2007/at07p240.pdf 
Morsy, M. A., Nigm, A. A, Sadek, R Rand El Rawy, A. (1990). Some production characteristic of Friesian and Jersey cattle in Libya. Dairy sci. Abs. 52, 2188. Egyptian J. Anim. Prod., (1989) 26(1), 15-34.

Mourad, K. A (1978). Some productive and reproductive characteristics of the Egyptian buffalo. M.Sc. Thesis, Cairo University, Cairo, Egypt.

Nartey, A.T. (1990). Lactation performance of Friesian cattle on the Accra Plains. BSc dissertation, Department of Animal Science, University of Ghana, Legon, Ghana. 57pp. AGRIS Categories: animal husbandry

Njubi, D.J, Rege, W., Thorpe, E., Collins-Lusweti and Nyambaka R. (1992). Genetic and environmental variations in reproductive and lactational performance of the Jersey cattle in the coastal lowland semi-humid tropics. Tropical Anim. Hlth. Prod., 24, 231-241. http://dx.doi.org/10.1007/BF02356752

Petrovic,M. (1992). The effect of sire on phenotypic parameters of lifetime dairy performance of Friesian cows. Anim. Breed. Abs., 60 (10), 6305. Stocarstvo. (1988) 42 (11/12), 429-440.

Roy Choudhury,P.N (1971). Service period, calving interval and dry period in Italian buffaloes. Zentralbatt fur Veterinas Medizin A 17: 284-287.
Santos, S.S.D., Ferreira, M.A.P, ima.,M.Y.S ., ampaio, R.V., Cordeiro MS., Silva, T.V.G., Costa,N.N.,Miranda,M.S and Ohashi,O.M (2011). Quantification, Morphology and Ultrastructure of Preantral Follicles of Buffalo (Bubalus bubalis) Foetuses. Reprod. Dom. Anim., 46: e17- e22.

SAS Users Guide: Statistics, Version 8.2 Edition. (1999). SAS Inst., Inc., Carry, NC.

Sattar, A.R H, Mirza,A.A K., Niazi,M and Latif M. (2005). Productive and reproductive performance of Holstein Friesian cows in Pakistan. Pakistan Vet. J., 25(2), 75-81.

Siddiquee, G.M, Rajane,K.R and Pande,M.S (1984). Effect of year and parity on some of the reproductive traits in Mehsana buffaloes. Livestock Advisor 9(10): 23-25

Skalicki,Z \& Latinovic,D. (1990). The influences of bull-sires on productive and reproductive traits, variation of cows in the black and white cattle population. Dairy Sci. Abst., 52, 4611.

Tantawy, M. A. M (1984). Studies on some traits in Egyptian buffaloes. M.Sc. Thesis, Moshtohor, Zagazig University, Egypt.

Zaki,H.O (1988). Productive and reproductive performance of primiparous buffaloes. M.Sc. Thesis, Ain-Shams University, Cairo, Egypt.

Zeidan,S.M (1990). Study of productive performance of Egyptian buffaloes. M.Sc. Thesis, Moshtohor, Zagazig University, Egypt. 


\section{الملخص العربي}

\section{تاثير بعض العوامل البيئية علي الآداء الانتاجى والتناسلى في الجاموس المصري}

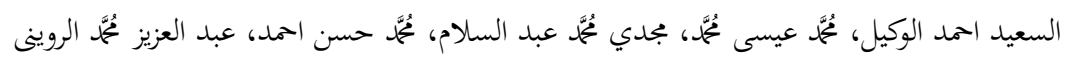

كان لموسم الولادة تاثير معنوي علي معظم الصفات المدروسة. تبين وجود تاثير معنوي لطول فترة الجفاف علي الفترة من الولادة وحتي الاخصاب (الفترة المفتوحة) وطول موسم الحليب ومحصول اللبن الكلي ولكن لم يكن هناك تاثير معنوي لطول فترة الجفاف علي الفترة

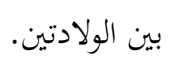

فقد وجد ان الفترة من الولادة حتي الاخصاب كانت اعلي في

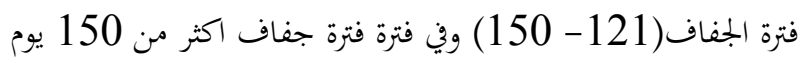

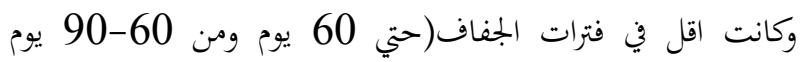

$$
\text { ومن90 يوم حتي } 120 \text { يوم). }
$$

طول موسم الحليب كان اعلي في فترة الجفاف من 60 -90 يوم وكان اقل في فترة جفاف من 121-150 يوم وفي فترة جفاف اعلي

$$
\text { من } 150 \text { يوم. }
$$

كان محصول اللبن الكلي اعلي في فترة جفاف من 60-90 يوم والاقل في فترة الجفاف الاكثر من 150 يوم. نستخلص من هذة الين

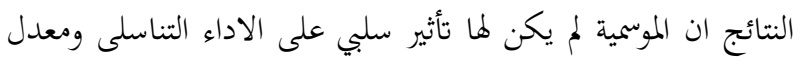

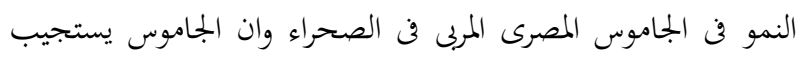
للرعاية الجيدة بدرجة عالية.
اجريت هذة الدراسة في مزرعة خاصة (تراست فارم) علي الطريق الصحراوي الاسكندرية القاهرة بعد مدينة العامرية بالتعاون مع كلية الزراعة-سابا باشا-جامعة الاسكندرية وكانت مدة الدراسة 3 سنوات وكانت تربية الجاموس في احواش(تربية مفتوحة) عدد الجاموسات 115 وعدد العجلات الاناث 71 تم استخدامهم في الدراسة وكانت اهم النتائج المتحصل عليها كالتالي: لم تؤثر التربية تحت الظروف الصحراوية علي اوزان العجلات عند الميلاد او عند الفطام او عند التلقيحة الاولي. كانت متوسط الفترة بين ولادتين 403.6 يوم وهذة قريبة جدا من الفترة القياسية والتي تكون ولادة كل سنة. وجد ان متوسط انتاج اللبن في الموسم 1600 كجم وهذة النتائج توضح ان الجاموس المصري يتاثر جيدا بالرعاية

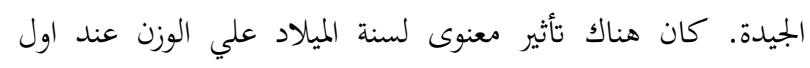
تلقيحة ومعدل النمو اليومي خلال الفترة من الفطام وحتي اول تلقيحة ومن الميلاد وحتي اول تلقيحة وايضا الفترة من الولادة حتي الاخصاب وطول موسم الحليب. 